\title{
92. 動態ファントムを用いたX線CT装置間の画像比較 Conparison of image of Xray-CT machines using motion phantom
}

慈恵医大病院放射線科 $\bigcirc$ 松尾浩一 杏雲堂病院放射線科
桜井 智生 松浦 宏 岡本 日出男

山口 武志 鹿野 和知

【目 的】X線CTの超高速化、Helical及びSpiralCTの実用化に伴い、動く物体の解 析が必要となってきたので動態画像の検討を行ない報告する。

【方法】】

使用機器. TOSHIBA TCT-900S, SIEMENS SOMATOM PLUS ,IMATORON C-100

・運動方向及びMIXDP ファントム ( fig 1)

・ファントムスピード：PLUS,900SのX,Y軸が10CM/SEC,その他30CM/SEC

【結果】〈X軸〉撮影時間：IMATRON 0.05SEC,その他 1SEC

上からPLUS,900S,IMATORON Spiral,Helical 単純な1SCAN後 (fig 2)

・肺野条件でPLUS,900Sは2個ある様に見えIMATORONでは1個Spiral,Helicalでは4個に見 える。

・縦隔条件では、はけてあとをひくほど肺野条件に比べ小さく見える。

・アー等ファクト条件では、PLUSはアーチファクトの多さが特に目立つが900S同様に

Spiral 、Helicalにすると解らない。

scan時間を変化させたもの ( fig 3)

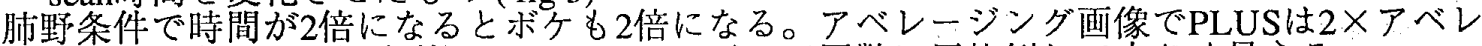
一ジ個に見える。縦隔条件では、アベレージング回数に反比例して小さく見える。 アーチファクト方向 (fig 4)

〈Y軸〉(fig 5) X軸と同様です。

〈Z軸〉(fig 6) IMATORONだけがきれいな円になって見え，PLUS,900Sは画像構成開始 位置と対画線上にアーチファクトを引いている。しかしSpiral,Helicalにするとそのアーチ

フ結論】1 1 消える般的撮影法に抬いて，PLUSは必ず上下又は左右方向IMATRONは左右方向 にアーチファクトを引く.900Sは不特定であり前処理が異なるように思える。2 装置 によらず短時間，NOアベレージング、360度未満の画像が有効である。3 画像、CT值の 歪みを認識していればSpiral,Helicalは全てにおいてアーチファクトが少ない為、体動があ る患者や呼吸停止不可の患者に応用できると思われる。4 超高速なSpiral,Helical-CTの360 度未满の画像を作成できれば

動態画像にはよりいっそう有効であると思われる。

fig 1

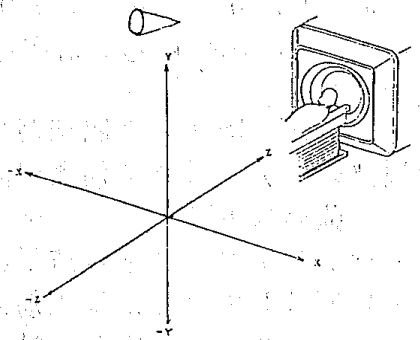

fig 4

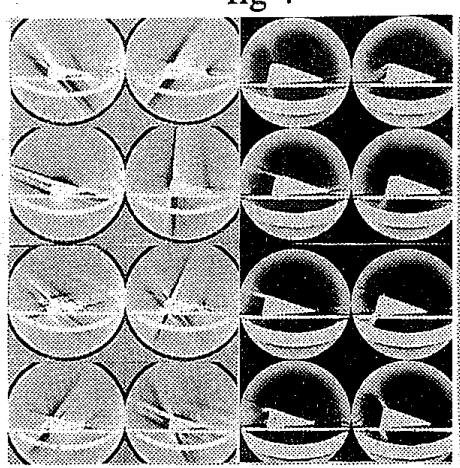

fig 2

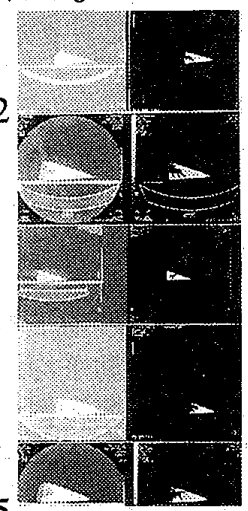

fig 5

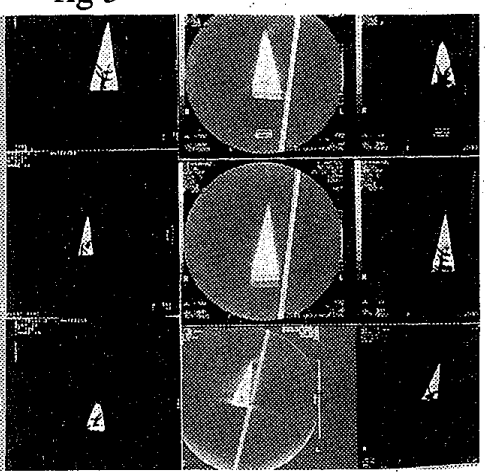

fig 3

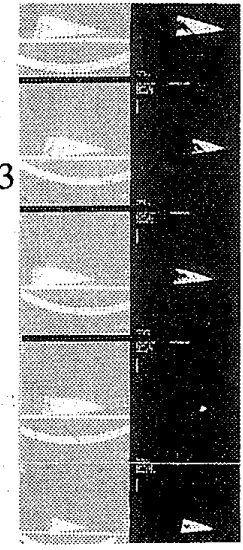

fig 6

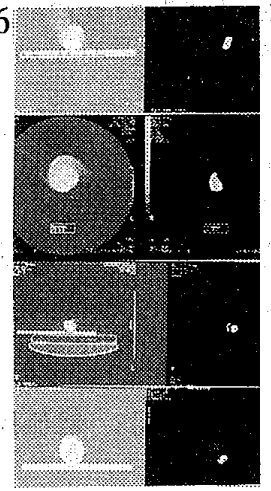

